\title{
The Evolution of the International Protection of Refugees between the World Wars
}

\section{Ivan A. Aleshkovski}

Lomonosov Moscow State University

\section{Zoya S. Botcharova}

Lomonosov Moscow State University

\section{Aleksandr A. Grebenyuk \\ Lomonosov Moscow State University}

\begin{abstract}
Based on the analysis of a wide historical factual and theoretical material, the article examines the history of refugees and the legal protection of forced migrants. The authors investigate the reasons for occurrence of norms and mechanisms of legal protection of the forced migrants due to the major refugee crises in modern and contemporary history (special refugee status, a simplified naturalization procedure for refugees, political asylum, the principles of non-extradition and nonrefoulement) and their adaptation at the national level. The research reveals the causes of the formation of the system of international legal protection of the rights of forced migrants in the 1920s - 1930s. Significant efforts were made under the League of Nations to regulate legal refugee status at the international level, to internationally and legally consolidate criteria according to which the refugee status can be acquired (depending on the origin, the affiliation of an exile to a specific state or specific ethnicity and the principle of 'lack of protection' from the country of origin). Special attention is paid to the analysis of the institutions created within the League of Nations' structure in order to solve the problem of refugees and instruments and mechanisms for settling the legal status of refugees (e.g., the 'Nansen passport'), the legal regulation of employment social welfare of forced migrants,
\end{abstract}

Social Evolution \& History, Vol. 20 No. 1, September 2021 109-132

(C) 2021 'Uchitel' Publishing House

DOI: $10.30884 / \mathrm{seh} / 2021.02 .05$ 
the improvement of the international system of refugee protection. The low efficiency of the activities of the institutions of the League of $\mathrm{Na}$ tions and legal mechanisms to solve the problem of refugees was established, and its causes were determined.

Keywords: League of Nations, forced migration, refugee, Nansen passport, High Commissioner for Refugees.

\section{A HISTORICAL PERSPECTIVE ON THE REFUGEE PHENOMENON AND EMERGING OF THE LEGAL PROTECTION OF FORCED MIGRANTS}

The refugee phenomenon has been known from time immemorial. Natural and ecological disasters, famine, epidemics, interethnic, political and religious conflicts, armed conflicts would result in massive forced migrations since ancient times that sometimes lead to refugee crisis.

One of the first historically documented refugee crises occurred in 721 BC after the Assyrian king Sargon II conquered Israel and its capital Samaria. As a result, tens of thousands of Israelites were banished and spread across the lands of the Assyrian Empire. They eventually assimilated with the locals. The Jewish conscience still bears the recollections of those events, and the legend of the Ten Lost Tribes is one of the most fascinating and persistent in Jewish History (Parfitt 2002).

The first known documented request for asylum was made to the Roman Emperor Valens by the Goths. In 375 the humanitarian disaster, accompanied by massive forced migrations, broke out on the vast territory between Rhine and Volga rivers where various barbaric tribes lived. The tribes of Huns from within Asia invaded the territory, crashing unstable primitive barbaric realms and ravaging everything on their way. A large mass of refugees amounting several thousand people including thousands of skilled soldiers crowded the banks of Danube where was the borderline between the Roman Empire and the Barbarians. The Goths sent their ambassadors to the Roman ruler Valens asking him to let them cross the river and to allocate lands in exchange for their service in the interests of the Empire. As was described by a Roman historian Ammianus Marcellinus,

the whole population of the tribe adopted this resolution unanimously... and having sent ambassadors to Valens, they humbly entreated to be received by him as his subjects, promising to live quietly, and to furnish a body of auxiliary troops of any necessity for such a force should arise (The Roman History... N.d.). 
The emperor Valens met the request of the Goths with sympathy and they were allowed to resettle in Roman provinces of Moesia and Thrace. There were so many refugees that, according to Ammianus Marcellinus, the Barbarians erupted into the Empire like the lava of Mount Etna. By the summer of 376, more than 200 thousand Goths were on the Roman side of Danube. Soon it became clear that the local authorities were unable to receive and feed such a large number of forced migrants. Besides Lupicinus, the commander of Roman troops in the Diocese of Thrace, appropriated the larger part of those means that were allocated on the needs of the Goths. The Goths rebelled and their army led by Fritigern moved towards Constantinople. Against them the legions of the East of the Empire were sent under the leadership of Emperor Valens. The decisive battle took place on August 9, 378 under Adrianople and completed with a total defeat of the Romans. The emperor Valens and 20 thousand legionaries fell in the battle. Only one third of the army survived. As Ammianus Marcellinus noted, 'nor, except the battle of Cannae, is so destructive' (The Roman History... N.d.). The Battle of Adrianople changed the European history forever, entailing the whole range of events, which a century later would lead to the vanishing of the Western Roman Empire.

An emerging practice of an organized refugee resettlement was connected to the Jewish expulsion from Spain in the fifteenth century. In March 1492, the Alhambra Decree was issued, which ordered all the Spanish Jews to either baptize or to leave Spain within four months. As a result, more than hundred thousand Jews were forced to leave Spain and take refuge in Portugal, France, the Netherlands, the Ottoman Empire and other countries. The exile became a national disaster for the Jews, that is why year 1492 is so important for the Jewish history, as well as the American one. Christopher Columbus begins his diary in the following way: '.. this present year $1492 \ldots$ after having expelled the Jews from your dominions, your Highnesses, in the same month of January, ordered me to proceed with a sufficient armament to the said regions of India' (Journal of the First Voyage... N.d.).

The Ottoman Empire provided refugees with favourable conditions and assistance. In August 1492, Bayezid II, sultan of the Ottoman Empire, sent the Ottoman Navy to Spain to save Jews who were expelled by the Spanish Inquisition. He also addressed a firman (sultan's decree) to the governors of his European provinces, which stated the following: '...the Jews of Spain should not be refused but rather welcomed with warm feelings and those who move against his decree and treat immigrants bad or cause any damage, however small it may be, shall be punished with a death sentence.' Sultan granted the refugees the permission 


\section{Social Evolution \& History / September 2021}

to settle in the Ottoman Empire and he allowed them to have all rights, which other subjects of the Empire had. Bayezid criticized the Spanish rulers for the Alhambra Decree: 'You venture to call Ferdinand a wise ruler, he who has impoverished his own country and enriched mine!' (Schulze, Blackmon, and Rose N.d.) Jew of Sephardic origin (Sefarád (sěphāradh) means 'Spain' in Hebrew) contributed much to the rising power of the Ottoman Empire by introducing new ideas, methods and craftsmanship in the development of military art, book printing, medicine, commerce and other spheres of social life of the Ottoman Empire.

In modern times the refugee crises are closely connected to the formation of the modern nation-state system in Europe, a lengthy and complicated process that began in the sixteenth century with the consolidation of feudal kingdoms into centralized states (Mavroudi and Nagel 2016). One of the most important factors, which influenced the consolidation of the system of international relations and development of the states of new type, was the Reformation. By strengthening an ideological factor, splitting Europe into Catholic and Protestant, bringing together opposite parties, the Reformation led to the confessional factor taking the lead in European politics. The Reformation also prompted the persecution of religious non-conformists, engendering massive forced migrations. By some estimates, there were as many as a million refugees at the beginning of the seventeenth century in Europe (Orchard 2019).

A notable example is the expulsion of half a million Huguenot French at the crossroads of the seventeenth and eighteenth centuries. In the result of these events a new word came into the English language. English-language dictionaries trace the origin of the word 'refugee' from the French refugié, or one who seeks refuge or safety. Thus, one of the questions during the session of the House of Commons in the British Parliament on 2 April 1695 related to French refugees. ${ }^{1}$

On 22 October, 1685 the French king Louis XIV signed The Edict of Fontainebleau, also known as the Revocation of the Edict of Nantes. The Edict of Fontainebleau stated that since 'the better and the greater part of our subjects of the said R.P.R. have embraced the Catholic faith,' the execution of Protestant cult in the kingdom was to be forbidden, the Protestant churches were to be destroyed, and within 15 days the Protestant priests were to choose whether to abdicate or to emigrate, so the Huguenots

together with their wives and children, against leaving our kingdom, lands, and territories subject to us, or transporting their goods and effects therefrom under penalty, as respects 
the men, of being sent to the galleys, and as respects the women, of imprisonment and confiscation. ${ }^{2}$

Many historians compare the Edict of Fontainebleau with the 1492 Alhambra Decree. By the time the Edict of Nantes was cancelled, there were approximately 800 thousand Protestants in France. The vast majority was forced to leave France for Britain, the Netherlands, Switzerland, and German States. The revocation caused France to suffer a kind of an early brain drain, as it lost a large number of professional people (scientists, silversmiths, watchmakers, doctors, merchants, etc.). Upon leaving France, the Huguenots took with them the knowledge of important techniques and knowledge contributing to economic and technological development of regions to which they relocated (Hornung 2014: 86).

According to the Westphalian system of international relations, consolidated in the Peace of Westphalia 1648, the borders may remain open for refugees to cross, and the right to migrate (jus emigrandi), or an opportunity to leave the territory with all property, was reserved for subjects; governments tended to apply laissez-faire attitude towards the refugees that crossed their borders and encouraged the admission of migrants, recognizing the fact that those who could afford to travel would strengthen nation through their presence and wealth. But each nation reacted to refugee crisis in its own way and on an entirely ad hoc basis, no policies could be established on the supranational level. Frederick Wilhelm, Elector of Brandenburg, in response to the signing of the Edict of Fontainebleau issued the Edict of Potsdam in late October 1685, where he encouraged the Protestants to seek refuge in his country. In 1687, James II of England issued Declaration of Indulgence, or Declaration for Liberty of Conscience. The Declaration granted broad religious freedom in England by suspending penal laws enforcing conformity to the Church of England and granted toleration to the various Christian denominations within his kingdoms. In 1689, William III and Mary II issued the Declaration for the Encouraging of French Protestants to Transport themselves into the Kingdom of England. In 1709, the British Parliament passed the Act for Naturalization Foreign Protestants. In the preamble of the Act stated that 'the increase of people is a means of advancing the wealth and strength of a nation.' The effect of the Act was that all foreign Protestants could be 'naturalized', provided they swore allegiance to the government and received sacrament in any Protestant church (Gwynn 1985).

The term resettlement policy emerged in connection with Protestant expulsion from France. Thus, the governments of England and 
the Netherlands, which accepted the largest number of refugees, provided financial support to assist the Huguenots resettlement in other countries, while Swiss cantons negotiated with German States regarding migrant resettlement. The diplomats, the representatives of the Huguenots and envoys of German governors met in Frankfurt-uponMaine, transit centre for French refugees, to make an agreement on reception standards for migrants. ${ }^{3}$

The revolutions of the eighteenth and nineteenth centuries marked the start of a new era in the history of forced migrations and led to the emergence of a new type of forced migrants - the political refugee ('émigrés') - and to new policies for receiving such individuals. The French Revolution of 1789 was the reason for the first mass political emigration, and more than 129 thousand 'émigrés' were forced to leave France and they resettled in almost every European country, from Sweden to Sicily, from Portugal to Russia, as well as in countries of the New World.

After the French Revolution, the legislation highlighted for the first time the political character of the right of asylum. The 29 December 1791 Decree of the Legislative Assembly in France confirmed that political motives were the only reason for accepting foreigners, and French Constitution consolidated this principle: 'It serves as a place of refuge for all who, on account of liberty, are banished from their native country. These it refuses to deliver up to tyrants. ${ }^{4}$ Swiss Constitution of 1848 consolidated the right of cantons to provide political asylum, which was considered as an integral part of the sovereignty.

During the nineteenth century, different categories of forced migrants contributed to creating new administrative and political tools for dealing with these moving populations. Thus, the prohibition of expulsion or return of refugees was established in the European law. The United Kingdom was first to introduce this principle in the legislation. The 1826 Registration of Aliens Act hampered the British government from deporting refugees, thus recognizing that a refugee once granted asylum could not be returned. In 1853, it was claimed in the Times that asylum policy is one of the greatest values of the United Kingdom: 'every civilised people on the face of the earth must be fully aware that this country is the asylum of nations, and that it will defend the asylum to the last ounce of its treasure, and the last drop of its blood' (April and Diaz 2016). In 1833, Article 6 of the Belgian Extradition Act ('Loi sur les extraditions') enshrined the principle of the nonextradition of any political refugee, with the exception of those refugees who threatened public security. ${ }^{5}$ 
This principle was rapidly adopted by other European states (Orchard 2019). With it, provision of offering assistance to foreign refugees was rarely applied, as generally it was caused by the fact that public welfare policies for nationals were also not developed at the time (April and Diaz 2016).

As Elizabeth Mavroudi and Caroline Nagel (2016) pointed out, 'if the age of revolutions in Europe produced a kind of refugee that was persecuted for what he or she said or did, the era of nationalism produced a type of refugee who was persecuted for something the persecutor viewed him or her as being.' Thus, because of the politics of state deprivation, to which Ireland was subdued on the side of the United Kingdom between 1815 and 1850, about 3 million Irish were forced to exile and leave for the USA and Canada. In the 1840s, the Irish comprised nearly half of all immigrants to the United States. In 1839 French sociologist Gustave de Beaumont described the living conditions of the Irish in the following way: 'the Indian in his forests, and the Negro in his chains', 'in all countries... paupers may be discovered, but an entire nation of paupers is what never was seen' (Beaumont 2007).

Another example of the most intense massive forced population movements is the Jewish migration from the Russian Empire to the United States and Canada in the years 1881-1914. At the beginning of the 1880s tens of thousands of Russian Jews were forced to migrate in the result of a series of anti-Jewish mob violence 1881-1882 years (socalled 'pogroms') and of the 'Temporary rules on Jews,' according to which, as it was pointed out by a state secretary Egor Perets, 'the Jews had only to leave Russia.' Between 1881 and 1914 one and a half million Jews from the Russian Empire fled to the United States and another half a million left for other new world destinations. It is worth mentioning that starting from the second half of the 1880s the Jewish migration from the Russian Empire is of mostly economic character, yet, the rise of antisemitism also contributed greatly to that process (Boustan 2007).

\section{THE ROLE OF THE LEAGUE OF NATIONS IN THE EMERGING INTERNATIONAL LEGAL PROTECTION OF REFUGEES}

The twentieth century has been called the 'century of the refugee.' The British writer and critic John Berger points out: 'Ours is the century of enforced travel... the century of disappearance. The century of people helplessly seeing others, who were close to them, disappear over the horizon' (Berger 2003).

The mass forced movement during and after World War I affected millions of people. In 1920, an American Red Cross official Homer 
Folks noted: 'refugees all over Europe... for five years it had seemed that almost everybody going somewhere or expected to do so soon and, meanwhile, living in a makeshift fashion' (Gatrell and Zhvanko 2017: $2-3$ ). The enforcement of migrations from one country to another in the conditions of the rise of a nationalist spirit made governments introduce more careful restricting measures, develop selective conditions of accepting foreigners. A visa system was introduced, and it became unacceptable to cross borders and stay in a country without a foreign passport. World War I had revealed the inconsistence of existing mechanisms of the protection of forced migrants in the conditions of the global conflict and toughening of national legislation on migration and contributed to forced migration being seen by the world society as a serious humanitarian problem for the first time in history, which could have been solved only with the assistance of the whole world community.

The Treaty of Versailles of 1919 and the Covenant of the League of Nations emphasized social and economic factors of supporting international peace and safety. Thus, in the Covenant of the League of Nations it was singled out that 'the members of the League make efforts to guarantee and secure just and humane labour conditions for men, women and children on their own territories... the members will also make efforts to the establishment and support of necessary international organizations.' 6 However, the questions of security of and assistance for forced migrants were not discussed at the Versailles conference.

The situation became even worse because in the general flow of migrants there was a specific category - Russian exiles, who were chased out from their place of residence by a new political regime. The 1917 Revolution and subsequent Civil War made hundreds of thousands people leave Russia. The waves of Russian migrants swept over the border countries and became a burden to the national economies devastated by the war. In 1918, there were approximately 800 thousand Russian refugees in European countries (including the European part of Turkey). In total, from 1.5 million to 2 million people could have migrated in 1917-1922 from Soviet Russia (Aleshkovski and Bocharova 2018).

Searching the refuge in other countries, the former subjects of the Russian Empire found themselves in a legal vacuum as the state of residence, which as an institute stopped protecting their interests. More than that, the majority of them found themselves in terrible conditions, they had no means of subsistence, no legitimate documents for employment or for resettlement in other countries. The lawyer Alexander Yashchenko, one of the first refugees characterized the situation 
with a mass exodus of former subjects of the Russian Empire in the following way, 'All Russian people turned into people without government, without citizenship' (Yashchenko 2003).

On December 15, 1921, the Council of People's Commissars of the USSR issued the decree which contributed to the final transformation of Russian migrants into stateless people. Those who left Russia after October 1917 and would not receive Soviet foreign passports until $1^{\text {st }}$ of June 1922 were deprived of the right for the Russian citizenship (Ginsburgs 1957).

At first, the emergency assistance to Russian refugees was provided by the League of Red Cross Societies and the International Committee of the Red Cross (ICRC). However, public organizations' resources turned out to be insufficient, and the necessity arose to coordinate the forces on the intergovernmental level (Jaeger 2001).

Gustave Ador, president of the ICRC, attracted the attention of the League of Nations to the catastrophic situation with Russian refugees. In his letter of February 20, 1921 addressed to the League of Nations he highlighted the resource constraints of international organizations and particular governments in the solution of the problem of Russian refugees. He also specified the lack of means for repatriation, settlement, employment, and material help for such a great group of forced migrants. Ador singled out that the League of Nations was the only international political force, which was in a position to surmount the political and social difficulties and to furnish a solution of the problem of Russian refugees.7 The choice of the League of Nations as an organization protecting the Russian refugees, was caused by its special status in the Versailles system of international relations, a moral authority and understanding the problems of those governments that sheltered refugees (Holborn 1939).

The started intergovernmental coordination in the legal regulation of forced migrations was stated in a corresponding resolution made by the Council of the League of Nations on February 26, 1921. Later the problem was repeatedly analyzed by the main bodies of the League of Nations, whose archives preserve more than 2.5 thousand documents on the refugee issues.

On May 19, 1921, the Council of the League of Nations adopted the resolution on the issue of the Russian refugees, urging all governments to take part in the problem-solving, in particular, to provide transport to move to other countries, transit visas, material support and assistance in finding the job. ${ }^{9}$

On June 27, 1921, the Council of the League of Nations established the position of the High Commissioner dealing with the affairs 
of Russian refugees which was in accordance with the solution of the legal status of refugees, assistance in their repatriation, employment and assistance along with charitable organizations. Since September 1921, Fridtjof Nansen, Norwegian traveler and scientist, was appointed the High Commissioner on Russian refugees (Chetail 2003).

\section{'NANSEN PASSPORT' AS AN INSTRUMENT OF ADAPTATION AND SOCIAL SECURITY OF REFUGEES}

The first international conference on the issue of legal status of Russian refugees took place on August 22-24, 1921 in Geneva. At the conference there was raised the question of the identification cards for Russian refugees-apatrides to provide them with an opportunity to move from one country to another in order to reunite with their families, to find a job, and a permanent place to live, etc. ${ }^{10}$ Decisions adopted at the conference led to the idea that refugee identity cards should meet the requirements of both governments, which the refugees leave, and host countries, giving the refugees the freedom to move within the residence country. These identity cards should be recognized not only in the country that have such a document, but also in other countries. It was believed that this document would not only compensate for lack of foreign passports, but also create a uniform system of documents instead of those which refugees had and which were issued by the governors of Russian Empire, Russian missions abroad, consulates of neutral countries or the Whites. The leading idea of the decision-making by the governments-members of the League of Nations was an aspiration for saving their sovereignty and avoiding the necessity to make changes in the national legislation while still preserving the interests of refugees (Pestrova 1995).

After long debates on the name of its document ('Refugee's Certificate of Identity and Origin'), which later was named Nansen passport, the Fifth Commission of the League of Nations, responsible for the refugees' problem, finally agreed to change the initially chosen name 'Certificat de réfugie' to 'Certificat d'identité,' and the word 'refugee' was changed to 'Any person of Russian origin who did not acquire any other nationality' (White 2017).

In March 1922, the Council of the League of Nations discussed and approved the project of certificate, the latter stating that its owner should have got 'all assistance and patronage' as well as 'an opportunity to travel freely and stay in other countries. ${ }^{, 11}$ The Council also encouraged the governments to give the document and visa free. ${ }^{12}$

The 'Certificat d'identite' and the rules of its issue were adopted by the intergovernmental conference that took place in Geneva on July 
3-5, 1922. The receiver should have documents confirming his/her refugee status and identity (either a passport issued by the Tsar or the Provisional government, or a not renewed Soviet passport). The refugee with certificate was obliged to fulfill the requirements as all the residents of the country had, to pay tax for getting the certificate and its renewing. Nansen passport was a national identity card for refugees, and it lost its power if the refugee went to the territory of Soviet Russia. The passport was renewed annually. The right to issue the passport was assigned to the recipient countries, not the League of Nations, so the document was composed in two languages: of the issuing country and in French. ${ }^{13}$ Thus, the definition of 'refugee' first was formulated in the international law and was used in relation to a certain group of people - the former subjects of the Russian Empire.

Later the circumstances required to spread the use of certificate on other groups of people who also found themselves unprotected by the country of origin. On August 24, 1924 the Council of the League of Nations introduced the identity document for the Armenian refugees. It was identical in content to those given to Russian refugees. The only difference was that the accordance was supplemented by a right to return to the country that issued the documents 'in all cases if there is no reason to act differently, to make free transportation of refugees easily and to improve their economic position., ${ }^{14}$

Thus, the legal approach to regulate official status of refugees was first demonstrated in the introduction of Nansen passport - the first international document that classified a stateless person. Besides, this document allowed solving an important task of facilitating transborder travelling for people left without the patronage of their native countries. However, the document could not resolve all the difficulties with transportation and labour permits. Its presence also did not guarantee social security: the right to get disability allowance, sickness benefit and unemployment benefit. The fulfillment of the decision made by the League of Nations in respect to forced migrants remained voluntary. The criteria for people who had the right to get the document were not fully legally justified. This weakness was actively used by countries that restricted refugees in their right to get the certificate and, accordingly, in their right to be protected (Gatrell 2017).

It was important to have unified criteria of issuing Nansen passports, so at the Intergovernmental conference of 1926 the definition of a refugee was further elaborated. Thus, a Russian refugee was 'any person of Russian origin, who does not use or no longer uses the protection of the government of the USSR and who did not acquire any other citizenship'; an Armenian refugee - 'any person of 
Armenian origin who formerly used to be the subject of the Ottoman Empire and who does not use or no longer uses the protection of the government of Turkish Republic and who did not acquire any other citizenship. ${ }^{15}$

Thus, receiving the refugee status was possible under two conditions: 'absence of protection of state of origin' and 'absence of another citizenship' (Hatway 1984: 353). The liberalization of refugee transportation made for including the statement about the right to come back (i.e., about the annulment of 'return visa').

\section{THE IMPROVEMENTS IN THE INTERNATIONAL SYSTEM FOR THE LEGAL PROTECTION OF REFUGEES AT THE TURN OF THE 1920S AND 1930S}

Since the mid-1920s the social component added to the work with refugees. The International Labour Office (ILO), to which the High Commissioner for refugees was assigned from the direct submission to the secretariat of the League, suggested creating a special revolving fund to finance transportation, accommodation and employment. Taking into account the fact that the states were not inclined to take an active part in the establishment of the revolving fund and assigning the means for it, in 1926 there was introduced a tax of 5 golden francs, which was levied on both refugee certificates and other documents, which were indispensable for refugees to get. It was recommended the governments to give impoverished refugees free entry, exit and transit visas if there was a recommendation by the ILO. The tax payment was confirmed by the mark with the image of Nansen ('Nansen stamp'), which was put on the Nansen passport. Further on, the means of the fund were used for the needs of refugees for making relocation and settlement more comfortable, for repayable loans for the colonization and settlement of South America. Thus, despite complicated social and economic conditions of the 1920s, the High Commissioner Fridtjof Nansen in the collaboration with the ILO and national governments managed to help find a permanent job to more than 50 thousand refugees, and the total amount of unemployed refugees by 1928 diminished to 200 thousand people comparing with 400 thousand in 1925 (Holborn 1939: 131).

At the turn of the 1920s and 1930s the League of Nations had some experience in regulating the transportations of forced migrants, yet it did not exhaust the problem of the legal status of refugees, questions of social issues concerning refuges were of primarily importance. 
The intergovernmental conference on the legal status of refugees took place from 28 to 30 of June 1928 and there were adopted three international agreements: on the legal status of Russian and Armenian refugees; on the functions of representatives of the High Commissioner of the League of Nations; on the diffusion of some measures to other categories of refugees, which were adopted in favour of Russian and Armenian refugees. These agreements laid the basis for the establishment of the global system of international refugee protection and international refugee regime.

The Agreement on the legal status of Russian and Armenian refugees consolidated for the first time in international law a special refugee status among other categories of migrants. The Agreement suggested that the restricting measures concerning foreign workers were not applied to the refugees, and the latter were not exiled even if lacking entry visa, they would not be deprived of identity card and levied with taxes following the norms for the nationals; the agreement also alleviated the formalities such as prolongation or placing visas on refugee cards or transportations of refugees within the borders of the host country. ${ }^{16}$

Another innovation was the spread of regulations, which were formulated for Russian and Armenian forced migrants, on Turkish, Assyrian, Assyro-Chaldean and assimilated refugees. The principles of 'origin' and 'lack of protection from the country of origin' were preserved for calling a person refugee. Thus, an Assyrian, AssyroChaldean or assimilated refugee was 'any person of Assyrian or Assyro-Chaldean origin, and any person of Syrian or Kurdish origin, who does not use or no longer uses the protection of the government of his or her former citizenship and who did not acquire or does not have any other citizenship'; a Turkish refugee was 'any person of Turkish origin who formerly used to be the subject of the Ottoman Empire and who, according to the conditions of Lausanne Treaty of 24 July 1923, does not use or no longer uses the protection of the Turkish Republic and who did not acquire any other citizenship. ${ }^{, 17}$ Thus, the principles of 'origin' and 'lack of protection' remained crucial for a person to get the refugee status.

After Nansen's death in 1930, the eleventh Assembly of the League of Nations decided to abolish the position of the High Commissioner and to establish the Nansen International Office for Refugees as autonomous body. The Office was able to fulfill human rights functions. The activity of the Office was stopped on December 31, 1938. 


\section{THE 1933 CONVENTION RELATING TO THE INTERNA- TIONAL STATUS OF REFUGEES AS THE MAJOR ACHIEVEMENT OF THE ACTIVITY OF THE LEAGUE OF NATIONS}

On October 26-28, 1933 the intergovernmental conference was held in Geneva which was organized by the Secretariat of the League of Nations and the Nansen International Office for Refugees. The main result of the Conference was adoption of the Convention on the international status of refugees, whose provisions became obligatory for participating states. However, every government had the right to make its own remarks considering any aspect. The Convention stated that its participants opted for providing refugees with 'civil rights, free access to courts, safety and stability in relation to work, the means of professional activity, opportunity to work in industry and commerce, and in relation to travelling freely, admission to schools and universities. ${ }^{, 18}$ The principle of non-refoulement was first incorporated in the international law. The participants of the Convention committed not to exile refugees or prevent those who had a permit to live in the territory constantly from entering it, unless the above-mentioned measures impacted the state's security or public order. The Convention guaranteed for the refugees the right of free application to the courts, the right to get a legal assistance on the same terms as citizens, and that they would be free from paying for legal expenses. The Convention stated that restrictions imposed by the laws and decisions protecting the domestic labour market would not be implemented severely to the refugees, who permanently or temporarily live in the country. An important constituent part of the convention was the articles on social security of refugees (including social allowance in case of accidents, allowance in case of accidents, unemployment, disability benefits, allowance to elderly people, homeless children, pregnant and nurturing women). They guaranteed that the rights of forced migrants would be equal to those of favourable foreign citizens. As for education, mutual benefit societies, fiscal regime etc., refugees were equal to nationals and to the most privileged foreigners. The refugee status continued to be defined on the basis of a group principle. ${ }^{19}$ Thus, the Convention on the international status of refugee was the first global document that analyzed the refugee problem in a comprehensive manner. 


\section{REORGANIZATION OF THE ASSISTANCE FOR REFUGEES AT THE END OF THE 1930S - 1940S}

The changes in the system of international relations in the 1930s led to the need to improve the criteria for acquiring the refugee status. In 1936, an international non-governmental organization the Institute of International Law adopted a resolution 'On the legal status of stateless persons and refugees,' which defined refugee in the following way, 'any person, who, for the reason of political events on the territory of the country of origin, left it willingly or unwillingly, and who did not acquire new citizenship and did not benefit from the diplomatic protection of any other state. ${ }^{20}$ Thus, the principles of 'lack of protection' from the country of origin and 'absence of any other citizenship' were complemented by a political component.

The debates on the question of refugees continued more actively at the $18^{\text {th }}$ Assembly of the League of Nations in 1937. Previously it was assumed that by 1938 refugees would either return to the countries of origin or assimilate. However, in 1937 about 600 thousand refugees were still under the Office protection. The Office also continued working on issuing Nansen passports, verifying different documents, preparing requests on abolishing expulsion, material aid, admission to hospitals, shelters etc. However, largely due to the position of the USSR, it was decided to halt the work of the Nansen International Office for Refugees within the specified time frame.

In February 1938, the Convention on the status of refugees coming from Germany was adopted which defined 'refugees coming from Germany' as

a) people with or without German citizenship and who do not have any other citizenship with respect to whom it is defined that they do not use de jure or de facto the protection of the German government: b) people without citizenship who do not fall within the previous conventions or agreements, who left the territory of Germany after they had settled there, and with respect to whom it is defined that they do not use de jure or de facto the protection of the German government.

The Convention introduced certificates for 'refugees coming from Germany,' and defined that refugees had the right to transfer freely, stay and live on the territory to which the present Convention applied. Legal status of refugees in Germany was established in accordance with the regulations of the 1933 Convention. ${ }^{21}$ 


\section{Social Evolution \& History / September 2021}

In July 1938, the first Assembly of the international Committee for Refugees was held in Évian (France) at the suggestion of American president Franklin Roosevelt. In its resolution of July 14, 1938, the necessity to adopt a long-term programme was articulated, which would assist forced migrants in accordance with current migrant legislation and international practice of different states. For the first time it was suggested that the list of refugees should include those who did not leave the country of their permanent residence (Germany or Austria), but who were forced to migrate because of religious beliefs, political convictions, or racial identity. Thus, the principles of 'origin' and 'lack of protection' in the definition of refugees were supplemented with political and religious aspects. ${ }^{22}$

On the eve of its closure, the Nansen International Office for Refugees received the Noble Peace Prize that was spent on the needs of refugees.

Since January 1, 1939 the High Commissariat in London became the centre of international assistance instead of Nansen Office at the League of Nations. The High Commissar was in charge only of establishing contacts with refugee organizations 'in a way the Commissar finds expedient.' The system of protection, which had been thoroughly constructed for a long time, was left in the hands of the governments that hosted refugees.

The last international legal pre-war agreement was the 1939 Additional Protocol to the 1936 Provisional Arrangement and to the 1938 Convention on the status of refugees coming from Germany, which was meant to protect refugees from the territories of the former Republic of Austria occupied by Germany in March $1938 .^{23}$

\section{CONCLUSION}

The problem of forced migration from a historical perspective allows understanding the complexity and ambiguity of the refugee phenomenon. The first attempts to help forced migrants made by individual states related to migration crises of ancient times and were not consolidated in national laws.

The idea that people, forced to leave the country of residence and left without its protection, needed to have a specific approach was firstly realized in the modern era. This period witnesses the emergence of norms forming the basis of the contemporary international approach to the problem of refugees, including the ideas of specific refugee status, international cooperation in solving refugee problems, and a simplified naturalization. Yet these norms were applied on an informal basis only, and the decision made at international level depended 
on specific circumstances (ad hoc), and states could close the borders for forced migrants at any time.

In the nineteenth century, refugees were considered as people forced to migrate for the reason of either political or religious persecution and who should have the right to leave the country of residence, to get an asylum in the host country and in relation to whom the principles of non-extradition and non-refoulement could be applied. Yet at that time the assistance to refugees was not provided by the host countries, and refugees had the right to stay in the territory of the country while they were able to take care of themselves.

The necessity to act in a global coordinated way was realized by the international community only at the beginning of the twentieth century after the humanitarian disaster provoked by World War I and the Russian Revolution. International legal protection of refugees, which began with the question of Russian refugees in 1921, by the end of the 1930s had been spread to other categories of refugees. The content of the definition 'refugee' changed greatly since its introduction to international law was conditioned primarily by the reaction of the international community to the twentieth-century refugee crises. Initially, in the 1920s the categories of refugees were defined according to the nationality or geographical position. The refugee status was applied in case of 1) 'lack of protection' from the country of origin and 2) 'absence of any other citizenship.' In the 1930s, the principle of political, religious or ethnic persecution was added. After World War II the group principle underlying the definition 'refugee' and formulated as attribution to a particular government, which could be the reason of their pursuit, was abolished. The individual principle was prioritized based on the protection of the rights of an individual.

In the 1920s - 1930s, the institutes dealing with refugee assistance appeared for the first time. These are the following institutional stages in the organization of refugee assistance: the High Commissariat for Russian refugees (after 1924 the word 'Russian' was omitted); the Nansen International Office for Refugees (1931-1938); the Office of the High Commissioner for Refugees from Germany (1933-1938); the Office of the High Commissioner of the League of Nations for Refugees (1933-1946); and the International Committee for Refugees (1938-1947). Permanent improvements were introduced in legal documents regulating the procedure of issuing refugee identities, their allocation and transportations. However, to put these initiatives into practice, it was necessary to have a good will of national governments. Not only administrative solution of the problem dependent on them, 
but also the introduction of new laws or the implementation of already adopted ones contributed to protection and integration of refugees.

The formation of the system for refugee protection during the interwar period reached its peak with the adoption of Convention of October 28, 1933 on refugee legal status. In fact, it became a compromise that took into account the norms revealed in practice, customs, legislation, interests of particular states, and refugee's claims, humane principles of an international right, which was formed under the aegis of the League of Nations. However, the 1933 Convention was only ratified by eight states.

Although the results of international governmental cooperation on refugee protection from 1919 to 1939 were insignificant, the importance of this period can hardly be underestimated. It was determined by the fact that the very first and most difficult steps were made to eliminate the consequences of World War I. A certain base was created that allowed developing that system of protection. However, the problem was not fully resolved because of the strategic purpose to eliminate the problem quickly, shortage of material and financial means at the disposal of the League of Nations, which was necessary to subsidize expensive projects of assisting refugees. The members of the League of Nations in general confined to the adoption of international agreements; yet, they did not hurry to ratify them. Moreover, it was possible to make remarks while signing the documents, and the principles of universality and uniformity were not fulfilled when some countries were ratifying the developed and internationally adopted binding agreements. It is necessary to mention that in the $1920 \mathrm{~s}$ 1930s the immanent traits of refugee context were formed, which are now easily traced in international law. Even nowadays there remain contradictions that emerged at that period in the legal space of refugees, when the sovereignty principle of states clashes with humane principles and this severely confines the efficiency of help to forced migrants in the modern world.

In the second half of the twentieth century the activity of the international community in the field of forced migrants largely expanded. Due to bloodshed armed conflicts, natural and man-induced catastrophes of the second half of the twentieth century and the beginning of the twenty-first century, the world community gained an abundant experience of work with forced migrants. Besides, the successor of the High Commissioner on Russian refugees, the United Nations High Commissioner for Refugees (UNHCR), known as the UN Refugee Agency, developed principles of legal protection of refugees established between the world wars. 
The contemporary international refugee regime was formed after World War II. According to the Statute of UNHCR, the Convention of July 28, 1951 and the Protocol of January 31, 1967, five criteria were defined, which hardly cover the whole range of reasons for forced migration even nowadays. There was removed the criterion of lack of protection from the country of origin or residence in defining refugees and the regulation that a refugee was a foreigner or a stateless person.

There emerged new reasons and causes for leaving the country of origin or residence, which led to adoption of thirty more international agreements and about twenty regional documents concerning refugees. They were the reaction in emerging crises of the 1960s, 1970s, and the 1980s. The recent years have been marked with great demand for assistance on the part of UNHCR because of the long-lasting conflicts in the Middle East, Africa and other regions.

Starting from the 1960s, the UNHCR took some new categories of forced migrants under its protection (as a rule, it was done on the request of the UN General Assembly), and the action of the mandate was extended. First of all, innovations largely concerned the migrants forced to leave the territory of the country because of wars or armed conflicts and their consequences. The main criterion remained the same - lack of the opportunity or unwillingness of the country of origin to give protection. As a result, two statuses were distinguished nowadays in the international law: 'mandate refugee' (i.e. individuals considered by UNHCR to be refugees according to the definition of its Statute and the 1951 Convention, or under the broader mandate subsequently bestowed by General Assembly and ECOSOC resolutions) and 'conventional refugees' (i.e. individuals determined to be refugees by the authorities of States that have acceded to the 1951 Convention and/or 1967 Protocol).

Nowadays UNHCR uses the following definition for an effective functioning of the system of international protection for refugees 'people in need of international protection,' including refugees, asylum seekers, repatriates, stateless and internally displaced persons. ${ }^{24}$

The global character of the refugee problem, which was noted in the resolution at the $1^{\text {st }} \mathrm{UN}$ General Assembly in 1946, remains relevant. By the end of 2020, there were more than 82.4 million people forcibly displaced worldwide, among which there were 48 internally displaced persons, 26.4 million refugees and 4.1 million asylum seekers. According to UNHCR, every day 37 thousand people forcibly move as a result of conflicts or persecutions in their countries of origin, which is approximately considered as one forced migrant in two seconds. ${ }^{25}$ Despite the fact that the greatest part of modern mi- 
grants find refuge in developing countries, it was premature to expect the end of 'the refugee era' in Europe at the end of the twentieth century (Marrus 1985: 348). It was clearly demonstrated by the European migration crisis of 2015-2017.

Modern refugee crises engendered new activities on global, regional and national levels. However, one should note that there are many difficult intricacies that are not easy to resolve even nowadays. There are several reasons for this. First, the channel of forced migration transforms into a relatively accessible legalization mechanism for change of place of permanent residence. This leads to increasing and intensifying flows of people, and it also diminishes targeting and share of refugees who really get a comprehensive assistance. The second important problem is the growing dissatisfaction of the population with host countries. This dissatisfaction with years becomes more statistically and sociologically visible (Betts and Milner 2019).

Nowadays the world community has made a quantum leap in increasing the assistance to forced migrants on the global level. On December 10-11, 2018 the UN countries adopted the Global Compact on Refugees. The Global Compact has four main objectives: to ease the pressure on host countries; to increase economic independence of refugees; to increase the number of refugees who move to third countries; and to contribute to the creation in the countries of origin of the conditions for a safe and secure return. ${ }^{26}$ Despite the fact that the Global Compact has no legal effect, it reflects the political will and ambition of the international community to strengthen international cooperation and show more solidarity with refugees and host countries.

\section{ACKNOWLEDGMENT}

This research was performed according to the Development program of the Interdisciplinary Scientific and Educational School of Lomonosov Moscow State University 'Mathematical Methods of Complex Systems' Analysis. The authors would like to thank the Russian Foundation for Basic Research (RFBR) for supporting the present research (grant No.19-511-93002).

\section{NOTES}

${ }^{1}$ House of Commons Journal, Volume 11, 9 April 1695. URL: https://www. british-history.ac.uk/commons-jrnl/vol11/pp297-298\#h3-0007. Accessed August 30, 2020.

2 Edict of Fontainebleau (October 22, 1685). URL: http://huguenotsweb. free.fr/english/edict_1685.htm. Accessed August 30, 2020. 
${ }^{3}$ Confessional Migration of the Reformed: The Huguenots. URL: http://iegego.eu/en/threads/europe-on-the-road/confessional-migration/ute-lotz-heumannconfessional-migration-of-the-reformed-the-huguenots. Accessed August 30, 2020.

4 French Constitution, 1793. URL: https://oll.libertyfund.org/pages/1793french-republic-constitution-of-1793. Accessed August 30, 2020.

5 Loi sur les extraditions 1er Octobre 1833. URL: http://reflex.raadvstconsetat.be/reflex/pdf/Mbbs/2009/12/18/57905d.pdf. Accessed August 30, 2020.

6 Treaty and protocol signed at Versailles June 28, 1919. URL: https:// history.state.gov/historicaldocuments/frus1919Parisv13/ch25. Accessed October 24, 2020.

7 La letter suivante du Comité International de la Croix-Rouge est communiquée au Conseil, pour examen, et aux Members de la Société, à titre d'information. URL: https://biblio-archive.unog.ch/Dateien/CouncilMSD/C-132-M73-1921_EN.pdf. Accessed August 30, 2020. See also Grahl-Madsen 1983: 358.

${ }^{8}$ Official Document System United Nations. URL: https://search.un.org/ Accessed October 30, 2020.

${ }^{9}$ Russian Refugees. Adopted by the Council of the League on May 19, 1921. C. 462. M. 343. 1921. Geneva, 1921. P. 3.

${ }^{10}$ Conference on the Question of Russian Refugees. Resolutions adopted by the Conference on August 24 $4^{\text {th }}, 1921$; League of Nations, Official Journal. $2^{\text {nd }}$ year. 1921. October. No. 8. P. 899-902.

11 Russian Refugees. Note by Secretary-General. 17 ${ }^{\text {th }}$ March 1922. C.130.M.77.1922. Geneva, 1922.

12 Russian Refugees. Resolution regarding Russian Refugees adopted by the Council at Paris, on March 25th 1922. C. 159(a).M.112.1922. Geneva, 1922. 3 p.

13 Arrangement with regard to the Issue of Certificates of Identity to Russian Refugees was signed in Geneva on July 5, 1922. League of Nations, Treaty Series. Vol. XXX. 1922. No. 855: 238-242.

${ }^{14}$ Identity Certificate for Armenian Refugees. Report by the High Commissioner. C.386.M.141.1924. Geneva, 1924.

15 Arrangement Relating to the Issue of Identify Certificates to Russian and Armenian Refugees, 12 May 1926, League of Nations, Treaty Series Vol. LXXXIX, No. 2004. URL: https://www.refworld.org/docid/3dd8b5802.html. Accessed August 30, 2020.

${ }^{16}$ Arrangement Relating to the Legal Status of Russian and Armenian Refugees, 30 June 1928, League of Nations Treaty Series, Vol. LXXXIX, No. 2005. URL: https://www.refworld.org/docid/3dd8cde56.html. Accessed August 9, 2020.

17 Arrangement Concerning the Extension to Other Categories of Certain Measures Taken in Favour of Russian and Armenian Refugees, 30 June 1928, League of Nations, Treaty Series, 1929; 89 LoNTS 63. URL: https://www.ref world.org/docid/42cb8d0a4.html. Accessed August 9, 2020. 
${ }^{18}$ Convention Relating to the International Status of Refugees, 28 October 1933, League of Nations, Treaty Series Vol. CLIX No. 3663. URL: https://www. refworld.org/docid/3dd8cf374.html. Accessed August 9, 2020.

${ }^{19}$ Convention Relating to the International Status of Refugees, 28 October 1933, League of Nations, Treaty Series Vol. CLIX No. 3663. URL: https:// www.refworld.org/docid/3dd8cf374.html. Accessed August 9, 2020.

20 Statut juridique des apatrides et des réfugiés. URL: http://www.idiiil.org/app/uploads/2017/06/1936_brux_02_fr.pdf. Accessed August 9, 2020.

${ }^{21}$ Convention concerning the Status of Refugees Coming from Germany, 10 February 1938, League of Nations Treaty Series, Vol. CXCII, No. 4461, page 59. URL: https://www.refworld.org/docid/3dd8d12a4.html. Accessed August 9, 2020.

${ }^{22}$ International Assistance to Refugees. Inter-governmental Committee. Evian, July $6^{\text {th }}-15^{\text {th }}, 1938$. C.244.M.143.1928.XII. Geneva: League of Nations, 1938. 2-3 p.

${ }^{23}$ Additional Protocol to the Provisional Arrangement and to the Convention (signed at Geneva on July 4th, and February 10th, 1938), respectively, concerning the Status of Refugees coming from Germany. URL: https://www.refworld.org/ pdfid/3dd8d1fb4.pdf. Accessed August 9, 2020.

${ }^{24}$ An Introduction to International Protection. URL: https://www.unhcr.org/ publications/legal/3ae6bd5a0/self-study-module-1-introduction-internationalprotection-protecting-persons.html. Accessed August 9, 2020.

${ }^{25}$ Global Trends in Forced Displacement in 2020. Geneva: UNHCR, 2020. P. 2.

26 The Global Compact on Refugees. URL: https://www.unhcr.org/theglobal-compact-on-refugees.html. Accessed August 9, 2020.

\section{REFERENCES}

Aleshkovski, I., and Bocharova, Z. 2018. The Phenomenon of 'Russia Abroad': Features of Forging and Maintaining National Identity. Istoriya 9 (8/72). URL: https://history.jes.su/s207987840002464-9-1/. DOI: 10.18254/S0002464-9-1. Original in Russian (Алешковский И. А., Бочарова 3. Феномен «Зарубежной России»: особенности формирования и сохранения национальной идентичности. История 9 (8/72).

Aprile. S., and Diaz, D. 2016. Europe and its Political Refugees in the $19^{\text {th }}$ Century. Books and Ideas, April 18. URL: https://booksandideas.net/ Europe-and-its-Political-Refugees-in-the-19th-Century.html. Accessed August 30, 2020.

Beaumont, G. 2007. Ireland. Social, Political, and Religious. Harvard: Belknap Press.

Berger, J. 2003. Selected Essays. Ed. by Geoff Dyer. New York: Pantheon books.

Betts, A., and Milner, J. 2019. Governance of the Global Refugee Regime. World Refugee Council Research Paper No. 13, May. URL: https://www. 
cigionline.org/publications/governance-global-refugee-regime. Accessed $\mathrm{Au}-$ gust $1,2020$.

Boustan, L. P. 2007. Were Jews Political Refugees or Economic Migrants? The Persecution Theory of Jewish Emigration, 1881-1914. In Hatton, T. J., O'Rourke, K. H., and Taylor, A. M. (eds.), The New Comparative Economic History. Essays in Honor of Jeffrey G. Williamson (pp. 267-290). Cambridge, Massachusetts, London: The MIT Press. URL: https:// scholar.princeton.edu/sites/default/files/lboustan/files/research06_jewishmigrat ion.pdf. Accessed August 20, 2020.

Chetail, V. 2003. Fridtjof Nansen and the International Protection of Refugees: an Introduction. Refugee Survey Quarterly 22 (1): 1-6.

Gatrell, P., and Zhvanko, L. 2017. Europe on the Move: Refugees in the Era of the Great War. Manchester: Manchester University Press.

Gatrell, P. 2017. The Nansen Passport: The Innovative Response to the Refugee Crisis that Followed the Russian Revolution. The Conversation, November 6. URL: https://theconversation.com/the-nansen-passport-the-innovative-respo nse-to-the-refugee-crisis-that-followed-the-russian-revolution-85487. Accessed August 10, 2020.

Ginsburgs, G. 1957. The Soviet Union and the Problem of Refugees and Displaced Persons 1917-1956. American Journal of International Law 51 (2): 325-361. DOI:10.2307/2195710.

Grahl-Madsen, A. 1983. The League of Nations and the Refugees. In The League of Nations in Retrospect / La Société des Nations: rétrospective (pp. 358-368). Proceedings of a Symposium organized by the United Nations Library and the Graduate Institution of International Studies. Berlin; New York: Walter de Gruyter.

Gwynn, R. 1985. England's 'First Refugees'. History Today 35 (5). URL: https://www.historytoday.com/archive/englands-first-refugees. Accessed August 30, 2020.

Hatway, J. 1984. The Evolution of Refugee Status in International Law: 1920-1950. The International and Comparative Law Quarterly 33 (2) (Apr.): 348-380.

Holborn, L. W. 1939. The League of Nations and the Refugee Problem. The Annals of the American Academy of Political and Social Science 203 (1) (May): 124-135.

Hornung, E. 2014. Immigration and the Diffusion of Technology: The Huguenot Diaspora in Prussia. Amer. econ. Review 104 (2): 86.

Jaeger, G. 2001. On the History of the International Protection of Refugees. IRRC 83 (843) (September): 727-737.

Marrus, M. 1985. The Unwanted: European Refugees in the Twentieth Century. Oxford: Oxford University Press. 
Mavroudi, E., and Nagel, C. 2016. Global Migration: Patterns, Processes and Policies. New York: Routledge.

Orchard, P. 2019. The Historical Development of Refugee Protection in Europe. In Weinar, A., Bonjour, S., and Zhyznomirska, L. (eds.) The Routledge Handbook of the Politics of Migration in Europe / New York: Routledge.

Parfitt, T. 2002. The Lost Tribes of Israel: The History of a Myth. London: Weidenfeld \& Nicolson.

Pestrova, K. 1995. The Evolution of International Refugee law: A Review of Provisions and Implementation. Cambridge Review of International Affairs 9 (2): 37.

Schulze, M., Blackmon, R. and Rose, Ch. N.d. History of the Jews of Turkey. A Document-Based Question Unit for World History. URL: https:// liberalarts.utexas.edu/mes/_files/pdf/curriculum/Turkish_Jews_DBQ.pdf.Acces sed August 30, 2020.

The Roman history of Ammianus Marcellinus, during the reigns of the emperors Constantius, Julian, Jovianus, Valentinian, and Valens (pp. 584 585). URL: https://archive.org/details/romanhistoryof00ammiiala/page/n6. Accessed August 30, 2020.

White, E. 2017. The Legal Status of Russian Refugees, 1921-1936. Comparativ. Zeitschrift fur Globalgeschichte und Vergleichende Gesellshaftsforschung. 27. Heft 1 (pp. 18-38).

Yashchenko, A. S. 2003. Legal Situation of the Russians Abroad. In Sorokina, V. V. (ed.), Russian Berlin (pp. 38-42). Moscow: Izdatel'stvo Moskovskogo universiteta. Original in Russian (Ященко А. С. Юридическое положение русских за границей // Русский Берлин / сост., предисл. и персоналии В. В. Сорокиной. М.: Изд-во Моск. ун-та). 